\title{
Indian Arts and Crafts in the United States
}

Much work is being done in the United States, under the direction of the Indian Arts and Crafts Board, to foster the development of traditional Indian arts, and to assist them to find their place in present-day industrial conditions, while at the same time preserving their original aesthetic quality. In a beautifully illustrated volume, Indian Art of the United States, published by the Museum of Modern Art, New York, appear photographs of a number of recent productions by Indian craftsmen. The editor of the book writes: "The basic soundness and vigour of Indian art are constantly producing articles that reflect the strength of Indian traditions and fit perfectly into the contemporary scene. As a matter of fact, Indian art not only has a place, but actually fills a concrete need in the United States to-day. Many contemporary tribal products can be used without adaptation in modern homes and as parts of modern dress: rugs, baskets, pottery, jewels, toys, fur garments, moccasins, gloves, bags, belts and embroideries. Navaho rugs are among the most durable floor coverings that can be found.' The writer goes on to point out that, though the demands of the tourist traffic have affected designs and colour, good Indian work, uninfluenced by white taste, leans to economy rather than complexity of design, and is notable for the close relationship between form and function and between design and material. Tribal craftsmen are adapting their products to fill new needs. As their own lives change, with the introduction of new means of transportation and other modern facilities, the scope of their experience grows and is reflected in a widening range of products, especially in the production of hand-woven materials, and new products in wood, silver, skin, and pottery. Silverware from Arizona, though made for the white man's use, retains the characteristics of the traditional tribal style. Modern Navaho rugs show how traditional designs blend with contemporary styles of decoration. Beaded and braided work from Oklahoma has been used in modern clothing.

Marjorie Lismer has described modern developments in the Seneca splint basketry industry, where the European and American demand has given a tremendous impetus to the industry, and has also had effects on the traditional forms and designs. Many new forms have been developed in response to the demands of white purchasers, and where formerly great differences in form existed among the basket-making tribes, there is now a certain similarity in basket shapes. 'But it is interesting to note that in each locality the techniques peculiar to the area are still an outstanding feature of the product.'

In Indians at Work, December 1938, an article describes how Mr. J. Preston Myers discovered that modern designs of great beauty were being produced by the Hopi. Mr. Myers made a collection of the best of these designs, and also sought to retrieve some of the ancient designs which were in danget of being lost. This enterprise soon became a village undertaking, and the designs, both ancient and modern, are being used and adapted in the village crafts.

Indian artists are employed to illustrate a series of bilingual readers for schools issued by the U.S.A. Office of Indian Affairs.

Mr. René d'Harnoncourt, General Manager of the Indian Arts and Crafts Board, in The Changing Indian, discusses the chief points to be considered in the development of Indian crafts and arts. These are: assistance to enable the craftsmen and artists to adapt their products to present-day needs, both of Indians and Whites, and the organization of markets. In advising the producer it is necessary to make him understand the function his products have to fulfil and also to make clear to him the requirements of modern marketing, such as standard prices and timely delivery. There is still a considerable market for Indian products within the producers' group: machine products, if available, are costly owing to transport costs; Local tradition often demands certain shapes and designs not supplied by imported 
goods. With the improvement of means of transport, of course, the local market will decline. There is, however, a definite and increasing market among the white population for useful household goods of high quality, and in the expansion of this market is the best opportunity for the sound development of Indian crafts. There is need for a greatly improved sales technique, for more knowledge on the part of those organizing sales, and for expert advice to the Indian producer to enable him to produce work which will respond to modern needs and tastes.

\section{Chinese Industrial Co-operatives}

THE first plans for the Chinese Industrial Co-operative movement were drawn up in 1937 by a group of Chinese and Americans in Shanghai, the leading spirit being the New Zealander, Rewi Alley. In 1938, Sir Archibald Clark-Kerr, British Ambassador to China, put the scheme before the Generalissimo and Madame Chiang Kai-Shek, through whom the support of Dr. H. H. Kung, Minister of Finance, was secured. With a small loan from the Ministry of Finance the work was started.

The purpose of the Chinese Industrial Co-operative movement was twofold: to replace the industries which had been destroyed or occupied by the Japanese, and without which neither the war effort nor the ordinary subsistence of the population could be maintained; and to provide work, hope, and a livelihood for the fifty million refugees from the war area.

Teams consisting of an engineer and an expert trained in co-operative methods were sent into every district of unoccupied China. The first Industrial Co-operative was formed among a group of blacksmiths in Paochi, a refugee centre in Shensi Province. From there the idea rapidly spread to other refugee centres. Within three months there were cooperatives making shoes, producing foodstuffs, blankets, towels, surgical cotton and gauze. Applicants soon outnumbered the capacity of organizing staffs.

One of the most spectacular achievements of the C.I.C. has been the production of blankets for the army. This effort was directly due to the leadership of Madame Chiang Kai-Shek. Thousands of spinners were trained, 7,500 spinning-wheels and hand-looms were manufactured-the aluminium for the wheels came from Japanese planes which were shot down-and by the end of 1942 nearly 3,000,000 blankets had been manufactured.

Co-operatives working in or near the war areas have to be prepared to move their plant and material at short notice; for this reason heavy industries have been located as far as possible from the battle front, and lighter industries have been so organized as to achieve the maximum mobility.

Women take an equal share with men in the co-operative movement, both as workers and organizers, and in the educational work which has developed as an integral part of it. Disabled soldiers, also, have found a place within the movement; they are making cigarettes and other consumers' goods in great demand, and so are enabled to become self-supporting instead of being a charge on the community.

The following account of the development of textile co-operatives shows how an ancient peasant craft has been developed to meet the needs of a modern nation at war:

' Since China depended on the coastal cities for textile supplies, the first large-scale efforts of the C.I.C. were to set up textile co-operatives. In some areas thread was still spun by the thumb and finger twisting method. It was not an unusual sight to see a grandmother sit in her doorway with a basket of raw wool, teaching a child how to draw the thread through her fingers. This, and the old spinning-wheel, were too leisurely processes to supply a nation at war, so Professor Lewis S. C. Smythe of the University of Nanking sought to develop an improved spinning-wheel, based on the type used in America I 50 years ago. An improved model was finally obtained from Mr. Sih Mingchien in Chungking, and after 